\title{
Structural and Spectral Characterization of a Chromium(III) Picolinate Complex: Introducing a New Redox Reaction
}

\author{
Mohammad Hakimi* \\ Chemistry Department, Payame Noor University, 19395-4697 Tehran, I. R. Iran. \\ "E-mail:mohakimi@yahoo.com
}

(Received August 21, 2013; Accepted September 22, 2013)

\begin{abstract}
Reaction between 2-pyridinecarboxylic acid (Hpic) and $\mathrm{K}_{3}\left[\mathrm{Cr}_{2}\left(\mathrm{O}_{2}\right)_{4}\right]$ give complex $\left[\mathrm{Cr}(\mathrm{pic})_{3}\right] . \mathrm{H}_{2} \mathrm{O}(\mathbf{1})$ which is characterized by elemental analysis and spectroscopic methods (FT-IR, Raman) and X-ray crystallography. In the crystal structure of 1, chromium atom with coordinated by three nitrogen and three oxygen atoms has a distorted octahedral geometry. Also a water molecule is incorporated in crystal network. Each water molecule acts as hydrogen bond bridging and connects two adjacent complexes by two $\mathrm{O}-\mathrm{H} \cdots \mathrm{O}$ hydrogen bonds.
\end{abstract}

Key words: Chromium(III) complex, Picolinate, Spectral characterization, X-ray crystal structure

\section{INTRODUCTION}

Pyridine derivatives are important intermediates widely used in the synthesis of drugs ${ }^{1}$ and pesticides. ${ }^{2}$ The structures and chemical properties of metal complexes of some pyridine carboxylates have been widely investigated. ${ }^{3}$ Some chromium complexes of the pyridine carboxylates have been known as potential bioavailable sources of chromium (III) as a model of glucose tolerance factor (GTF). ${ }^{3 \mathrm{a}, \mathrm{b}}$

We are interesting in design and synthesis of complexes with pyridine derivatives and also N,O-donor ligands. And in the past few years, we have published a series of paper in this field. ${ }^{4}$ In this paper preparation of the chromium(III) complex, $\left[\mathrm{Cr}(\text { pic })_{3}\right] \cdot \mathrm{H}_{2} \mathrm{O}(\mathbf{1})$, with 2-pyridinecarboxylic acid (Hpic, Scheme 1) is presented and spectroscopic characteristics (IR, Raman) and crystal structure of this complex are determined.

Study of the CSD structures by ConQuest revealed that the chromium atom has very different coordination numbers including two,${ }^{5}$ three,${ }^{6}$ four, ${ }^{7}$ five,${ }^{8}$ six,${ }^{9}$ seven, ${ }^{10}$ eight, ${ }^{11}$ nine, ${ }^{12}$ ten, ${ }^{13}$ eleven, ${ }^{14}$ twelve, ${ }^{15}$ and thirteen. ${ }^{16}$ In this paper we endeavored to introduce coordination aspect of the Hpic with chromium atom.

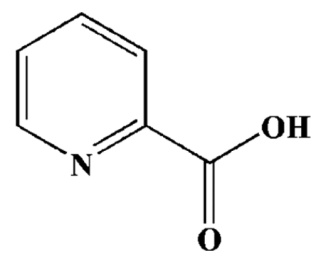

Scheme 1. Chemical structure of the 2-pyridinecarboxylic acid (Hpic).

\section{EXPERIMENTAL}

All starting chemicals and solvents were reagent or analytical grade and used as received. The infrared spectrum of a $\mathrm{KBr}$ pellet in the range $4000-400 \mathrm{~cm}^{-1}$ was recorded with a FT-IR 8400 -Shimadzu spectrometer. The carbon, hydrogen and nitrogen contents were determined in a Thermo Finnigan Flash Elemental Analyzer 1112 EA. The Raman spectrum was performed using a Nicolet Model 910 Fourier-transform spectrometer. The melting point was determined with a Barnsted Electrothermal 9200 electrically heated apparatus.

\section{Synthesis of $\left[\mathrm{Cr}(\mathrm{pic})_{3}\right] \cdot \mathrm{H}_{2} \mathrm{O}(1)$}

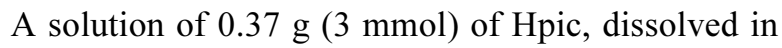
$\mathrm{H}_{2} \mathrm{O}(5 \mathrm{~mL})$, was added with stirring to a solution of $0.297 \mathrm{~g}(1 \mathrm{mmol})$ of $\mathrm{K}_{3}\left[\mathrm{Cr}\left(\mathrm{O}_{2}\right)_{4}\right]$ in $\mathrm{H}_{2} \mathrm{O}(15 \mathrm{~mL})$. The reaction mixture was stirred for $1 \mathrm{~h}$. Red crystals suitable for X-ray diffraction were obtained from the solution after standing for $7 \mathrm{~d}$. Yield: $0.284 \mathrm{~g}(65 \%)$. m.p. $>300{ }^{\circ} \mathrm{C}$. Anal. Calcd for $\mathrm{C}_{18} \mathrm{H}_{14} \mathrm{CrN}_{3} \mathrm{O}_{7}(\%)$ : C, 49.55; H, 3.23; N, 9.63. Found: C, 48.89; H, 3.23; N, 9.66. IR $\left(\mathrm{cm}^{-1}, \mathrm{KBr}\right): 3525 \mathrm{w}\left(v_{\mathrm{as}} \mathrm{H}_{2} \mathrm{O}\right), 3315 \mathrm{w}\left(\mathrm{v}_{\mathrm{s}} \mathrm{H}_{2} \mathrm{O}\right), 3063 \mathrm{w}$ ( $v \mathrm{CH}), 1680 \mathrm{~s}\left(v \mathrm{C}=\mathrm{O}\right.$ and/or $\left.\delta \mathrm{H}_{2} \mathrm{O}\right), 1605 \mathrm{~m}(v \mathrm{C}=\mathrm{N})$, $1470 \mathrm{~m}(v \mathrm{C}=\mathrm{C}), 1327 \mathrm{~s}, 1288 \mathrm{~m}, 1157 \mathrm{~m}(v \mathrm{CO}), 1049$ $\mathrm{w}(\nu \mathrm{CN}), 856 \mathrm{~m}, 764 \mathrm{~m}$ and $694 \mathrm{w}(\delta \mathrm{py}), 671 \mathrm{w}\left(\rho_{\mathrm{r}}\right.$ $\left.\mathrm{H}_{2} \mathrm{O}\right), 548 \mathrm{w}\left(v \mathrm{CrO}\right.$ and/or $\left.\rho_{\mathrm{w}} \mathrm{H}_{2} \mathrm{O}\right), 471 \mathrm{~m}(v \mathrm{CrN})$. Raman: $3025 \mathrm{~m}(v \mathrm{CH}), 1601 \mathrm{vs}(v \mathrm{C}=\mathrm{N}), 1485 \mathrm{w}(v$ $\mathrm{C}=\mathrm{C}), 1205 \mathrm{w}(v \mathrm{CO}), 1108 \mathrm{~m}(v \mathrm{CN}), 980 \mathrm{w}, 864 \mathrm{~m}$, $713 \mathrm{w}\left(\rho_{\mathrm{r}} \mathrm{H}_{2} \mathrm{O}\right), 616 \mathrm{~m}\left(v \mathrm{CrO}\right.$ and/or $\left.\rho_{\mathrm{w}} \mathrm{H}_{2} \mathrm{O}\right), 471 \mathrm{~m}(v$ $\mathrm{CrN}), 365 \mathrm{w}, 257 \mathrm{w}\left(\rho_{\mathrm{t}} \mathrm{H}_{2} \mathrm{O}\right)$. 


\section{Crystal Structure Determination and Refinement}

The data collection for $\mathbf{1}$ was carried out by Bruker APEX-II CCD diffractometer, using graphite-monochromated $\operatorname{MoK} \alpha(\lambda=0.71073 \AA)$ radiation at $296 \mathrm{~K}$. The data were integrated with SAINT and corrected for Lorentz polarization and absorption performed using SADABS. ${ }^{17}$ The structure was solved by Patterson methods, implemented in SHELXS-97. ${ }^{18}$ Refinement by full-matrix least squares methods based on $F^{2}$ values against all reflections has been performed by SHELXL-97, ${ }^{18}$ including anisotropic displacement parameters for all non-H atoms. The position of hydrogen atoms belonging to the carbon atoms $\mathrm{Csp}^{2}$ were geometrically optimized applying the riding model $\left[\mathrm{Csp}^{2}-\mathrm{H}, 0.93 \AA ; U_{\text {iso }}(\mathrm{H})=1.2 U_{\mathrm{eq}}(\mathrm{C})\right]$. Calculations concerning the molecular geometry, the verification of space group, the analysis of hydrogen bonds were performed with PLATON. ${ }^{19}$

CCDC 880374 for $\left[\mathrm{Cr}(\text { pic })_{3}\right] \cdot \mathrm{H}_{2} \mathrm{O}$ (1) contain the supplementary crystallographic data for this paper. These data can be obtained free of charge from The Cambridge Crystallographic Data Centre via www.ccdc.cam.ac.uk/ data_request/cif.

\section{RESULTS AND DISCUSSION}

\section{Synthesis and Spectroscopic Characterization}

Reaction of Hpic with a water solution of $\mathrm{K}_{3}\left[\mathrm{Cr}\left(\mathrm{O}_{2}\right)_{4}\right]$ in a molar ratio of 1:3 (M:L) give complex 1 (Scheme 2). The complex was air-stable and soluble in $\mathrm{H}_{2} \mathrm{O}$. Similar structure has been reported previously, ${ }^{20}$ but they used of different precursor, $\mathrm{Cr}\left(\mathrm{NO}_{3}\right)_{3} .9 \mathrm{H}_{2} \mathrm{O}$, under $\mathrm{pH}$ condition. The crystallography of $\mathbf{1}$ has been well done in low temperature than the previously report. Also meanwhile, this paper is presented new redox reaction which is interesting in coordination chemistry.

Suggested reaction equation is presented in Scheme 2. During the reaction, peroxide ligands are replaced by three pic and $\mathrm{Cr}(\mathrm{V})$ is reduced to $\mathrm{Cr}(\mathrm{III})$ by peroxide anions (Scheme 3). After reduction, buabbles of oxygen molecules are removed from the solution. Other peroxide onions which are not involved in reduction process are neutralized by $\mathrm{H}^{+}$ions from Hpic and $\mathrm{K}^{+}$of $\mathrm{K}_{3}\left[\mathrm{Cr}\left(\mathrm{O}_{2}\right)_{4}\right]$.

In the IR spectrum of Hpic, ${ }^{21}$ there is a bands at 1722 $\mathrm{cm}^{-1}$ which were assigned to the vibrations of the $v(\mathrm{C}=\mathrm{O})$.

$$
\begin{aligned}
2 \mathrm{~K}_{3}\left[\mathrm{Cr}\left(\mathrm{O}_{2}\right)_{4}\right]+6 \mathrm{Hpic}+2 \mathrm{H}_{2} \mathrm{O} \longrightarrow \\
2\left[\mathrm{Cr}(\text { pic })_{3}\right] \cdot \mathrm{H}_{2} \mathrm{O}+2 \mathrm{O}_{2}+3 \mathrm{H}_{2} \mathrm{O}_{2}+3 \mathrm{~K}_{2} \mathrm{O}_{2}
\end{aligned}
$$

Scheme 2. Suggested reaction equation for synthesis of $\left[\mathrm{Cr}(\mathrm{pic})_{3}\right]$. $\mathrm{H}_{2} \mathrm{O}$ (1).

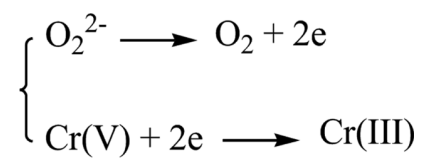

Scheme 3. Reduction of $\mathrm{Cr}(\mathrm{V})$ to $\mathrm{Cr}(\mathrm{III})$ by peroxide onion.

This band is shifted $42 \mathrm{~cm}^{-1}$ to lower energy in $\mathbf{1}$ indicating deprotonation of carboxylic acid group and coordination through the oxygen atom.

The presence of a water molecule in $\mathbf{1}$ affects the IR and Raman spectra in three regions including 3525 and 3315 $\mathrm{cm}^{-1}$ for asymmetric and symmetric $\mathrm{OH}$ stretches, 1680 $\mathrm{cm}^{-1}$ for $\mathrm{H}_{2} \mathrm{O}$ bending and $250-700 \mathrm{~cm}^{-1}$ for "librational modes". These modes are due to rotational oscillations of the water molecules restricted by interactions with neighboring atoms and they are classified into three types (wagging $\left(\rho_{\mathrm{w}}\right)$, twisting $\left(\rho_{\mathrm{t}}\right)$ and rocking $\left.\left(\rho_{\mathrm{r}}\right)\right)$ depending upon the direction of the principal axis of rotation. ${ }^{22}$ The ring wagging vibrations of the pyridine groups were also observed at 694 and $764 \mathrm{~cm}^{-1}$.

Information about the low frequency of metal-ligand vibrations can be obtained by Raman spectroscopy. ${ }^{23}$ In the Raman spectra of $\mathbf{1}$, the bands at 616 and $471 \mathrm{~cm}^{-1}$ were assigned to $\mathrm{Cr}-\mathrm{O}$ and $\mathrm{Cr}-\mathrm{N}$ stretching vibrations respectively. Similar results were reported previously. ${ }^{24}$ The X-ray analysis confirms the higher stretching vibrations of $\mathrm{Cr}-\mathrm{O}$ bond respect to the $\mathrm{Cr}-\mathrm{N}$.

\section{Description of the Crystal Structure}

The crystal structure of $\left[\mathrm{Cr}(\text { pic })_{3}\right] \cdot \mathrm{H}_{2} \mathrm{O}$ (1) has been determined by single-crystal X-ray diffraction analysis. Diagrams of the molecular structure and unit cell were created using Ortep-III ${ }^{25}$ and Diamond Mercury. ${ }^{26}$ Crystallographic data and details of the data collection and structure refinement are listed in Table 1. Selected bond lengths and angles for complex are listed in Table 2 and hydrogen bond distances, $d(\mathrm{H} \cdots \mathrm{A})$, and angles are presented in Table 3 .

In the crystal structure of $\mathbf{1}$ (Fig. 1), the chromium atom is coordinated by three nitrogen and three oxygen atoms of Hpic in distorted octahedral geometry (Fig. 2). Also a water molecule is presence present in this structure and trapped by hydrogen bonds. There are three five-membered chelate rings around the chromium atom which are almost planar (rms deviation $0.080 \AA$ for $\mathrm{O} 1$ ). The $\mathrm{Cr}-\mathrm{N}$ and $\mathrm{Cr}-\mathrm{O}$ bond distances in $\mathbf{1}$ are comparable with the analogous ones reported in the literature for complexes which contain dipicolinate coordinated to chromium(III) ion in an $O, N, O^{\prime}$-tridentate fashion. ${ }^{27}$

In the network of $\mathbf{1}$, each water molecule acts as hydro- 
Table 1. Crystal data and structure refinement for $\mathbf{1}$

\begin{tabular}{ll}
\hline Empirical formula & $\mathrm{C}_{18} \mathrm{H}_{14} \mathrm{CrN}_{3} \mathrm{O}_{7}$ \\
Formula weight $\left(\mathrm{g} \mathrm{mol}^{-1}\right)$ & 436.32 \\
Temperature $(\mathrm{K})$ & 296 \\
Crystal system & Monoclinic \\
Space group & $C 2 / c$ \\
Unit cell dimensions $\left.(\AA)^{\circ}\right)$ & \\
A & $30.143(7)$ \\
B & $8.4769(19)$ \\
C & $13.870(3)$ \\
B & $95.479(3)$ \\
Volume $\left(\AA^{3}\right), Z$ & $3528.0(14), 8$ \\
Calculated density $\left(\mathrm{mg} \mathrm{m}^{-3}\right)$ & 1.643 \\
Absorption coefficient $\left(\mathrm{mm}^{-1}\right)$ & 0.70 \\
$F(000)$ & 1784 \\
Crystal size (mm & $-3)$ \\
$\theta$ range for data collection $\left({ }^{\circ}\right)$ & $0.20 \times 0.10 \times 0.10$ \\
$h, k, l$ ranges & $1.4-24.8$ \\
Reflections collected & $-30: 35,-9: 10,-14: 16$ \\
Independent reflections & 8031 \\
$R_{\text {int }}$ & 3053 \\
Data / restraints / parameters & 0.048 \\
Goodness-of-fit on $F^{2}$ & $3053 / 0 / 270$ \\
Final $R$ indexes $[I>2 \sigma(I)]$ & 1.096 \\
$R$ indexes (all data) & $R_{1}=0.0380, w R_{2}=0.0848$ \\
Largest diff. peak and hole $\left(\mathrm{e} . \AA^{-3}\right)$ & $R_{1}=0.0635, w R_{2}=0.1116$ \\
\hline
\end{tabular}

Table 2. Selected bond length $(\AA)$ and angles $\left(^{\circ}\right)$ for 1 with estimated standard deviations in parentheses

\begin{tabular}{llll}
\hline Distances & & Angles & \\
\hline Cr1-N1 & $2.063(3)$ & N1-Cr1-O1 & $81.2(1)$ \\
Cr1-N2 & $2.055(3)$ & N2-Cr1-O3 & $80.8(1)$ \\
Cr1-N3 & $2.045(3)$ & N3-Cr1-O5 & $80.5(1)$ \\
Cr1-O1 & $1.945(2)$ & O1-Cr1-N2 & $170.7(1)$ \\
Cr1-O3 & $1.946(3)$ & O1-Cr1-N3 & $89.9(1)$ \\
Cr1-O5 & $1.955(2)$ & O1-Cr1-O5 & $94.4(1)$ \\
\hline
\end{tabular}

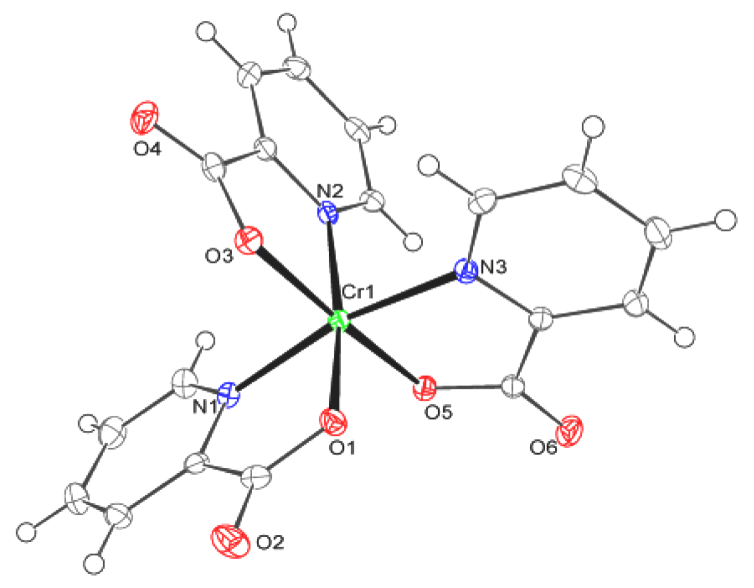

Figure 1. The ORTEP-III diagram of the molecular structure of 1. The ellipsoids are drawn at the $40 \%$ probability level. The water molecule has been omitted for clarity.

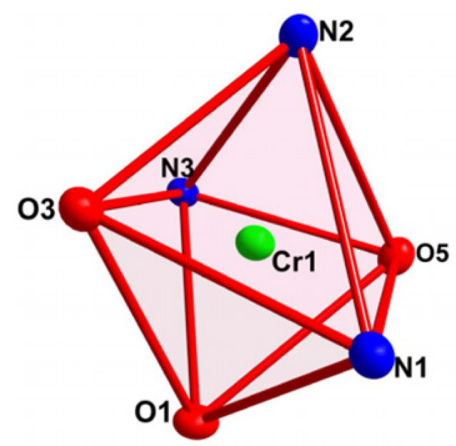

Figure 2. The distorted octahedral geometry for chromium atom in complex 1.

gen bond bridge and connects two adjacent complexes (Fig. 3). The $\mathrm{O} 7$ atom of $\mathrm{H}_{2} \mathrm{O}$ molecule participates in hydrogen bonding as a proton donor and connects $\mathrm{O} 5$ atom of one complex to $\mathrm{O} 2$ atom in other complex by strong hydrogen bonds (strong hydrogen bonds range in literature is $1.5-2.2 \AA^{28}$ ).

Table 3. Hydrogen bond geometries $\left(\AA,^{\circ}\right)$ for $\mathbf{1}$

\begin{tabular}{llllll}
\hline $\mathrm{D}-\mathrm{H} \cdots \mathrm{A}$ & $d(\mathrm{D}-\mathrm{H})$ & $d(\mathrm{H} \cdots \mathrm{A})$ & $<(\mathrm{DHA})$ & $d(\mathrm{D} \cdots \mathrm{A})$ & Symmetry code on A atom \\
\hline $\mathrm{C}(3)-\mathrm{H}(3 \mathrm{~A}) \cdots \mathrm{O}(2)$ & 0.929 & 2.340 & 142.5 & $3.129(5)$ & $x, 1-y, z-0.5$ \\
$\mathrm{C}(4)-\mathrm{H}(4 \mathrm{~A}) \cdots \mathrm{O}(4)$ & 0.930 & 2.709 & 130.0 & $3.383(5)$ & $0.5-x, 0.5-y,-z$ \\
$\mathrm{C}(6)-\mathrm{H}(6 \mathrm{~A}) \cdots \mathrm{O}(4)$ & 0.930 & 2.475 & 135.2 & $3.203(4)$ & $0.5-x, 0.5+y, 0.5-z$ \\
$\mathrm{C}(9)-\mathrm{H}(9 \mathrm{~A}) \cdots \mathrm{O}(6)$ & 0.930 & 2.405 & 170.0 & $3.149(4)$ & $-x, 1-y,-z$ \\
$\mathrm{C}(10)-\mathrm{H}(10 \mathrm{~A}) \cdots \mathrm{O}(5)$ & 0.930 & 2.593 & 160.9 & $3.485(5)$ & $x, 1-y, z-0.5$ \\
$\mathrm{C}(11)-\mathrm{H}(11 \mathrm{~A}) \cdots \mathrm{O}(3)$ & 0.930 & 2.638 & 135.3 & $3.363(5)$ & $x,-y, z-0.5$ \\
$\mathrm{C}(11)-\mathrm{H}(11 \mathrm{~A}) \cdots \mathrm{O}(7)$ & 0.930 & 2.608 & 138.3 & $3.359(5)$ & $x, 1-y, z-0.5$ \\
$\mathrm{C}(15)-\mathrm{H}(15 \mathrm{~A}) \cdots \mathrm{O}(7)$ & 0.930 & 2.227 & 154.9 & $3.095(5)$ & $x, y-1, z$ \\
$\mathrm{C}(16)-\mathrm{H}(16 \mathrm{~A}) \cdots \mathrm{O}(6)$ & 0.930 & 2.544 & 168.3 & $3.460(5)$ & $x, y-1, z$ \\
$\mathrm{C}(18)-\mathrm{H}(18 \mathrm{~A}) \cdots \mathrm{O}(1)$ & 0.929 & 2.606 & 129.6 & $3.277(4)$ & $-x, y, 0.5-z$ \\
$\mathrm{O}(7)-\mathrm{H}(7 \mathrm{~A}) \cdots \mathrm{O}(2)$ & 1.00 & 1.82 & 175 & $2.823(4)$ & $x, 1-y, z-0.5$ \\
$\mathrm{O}(7)-\mathrm{H}(7 \mathrm{~B}) \cdots \mathrm{O}(5)$ & 0.87 & 2.01 & 168 & $2.867(4)$ & $x, y, z$ \\
\hline
\end{tabular}




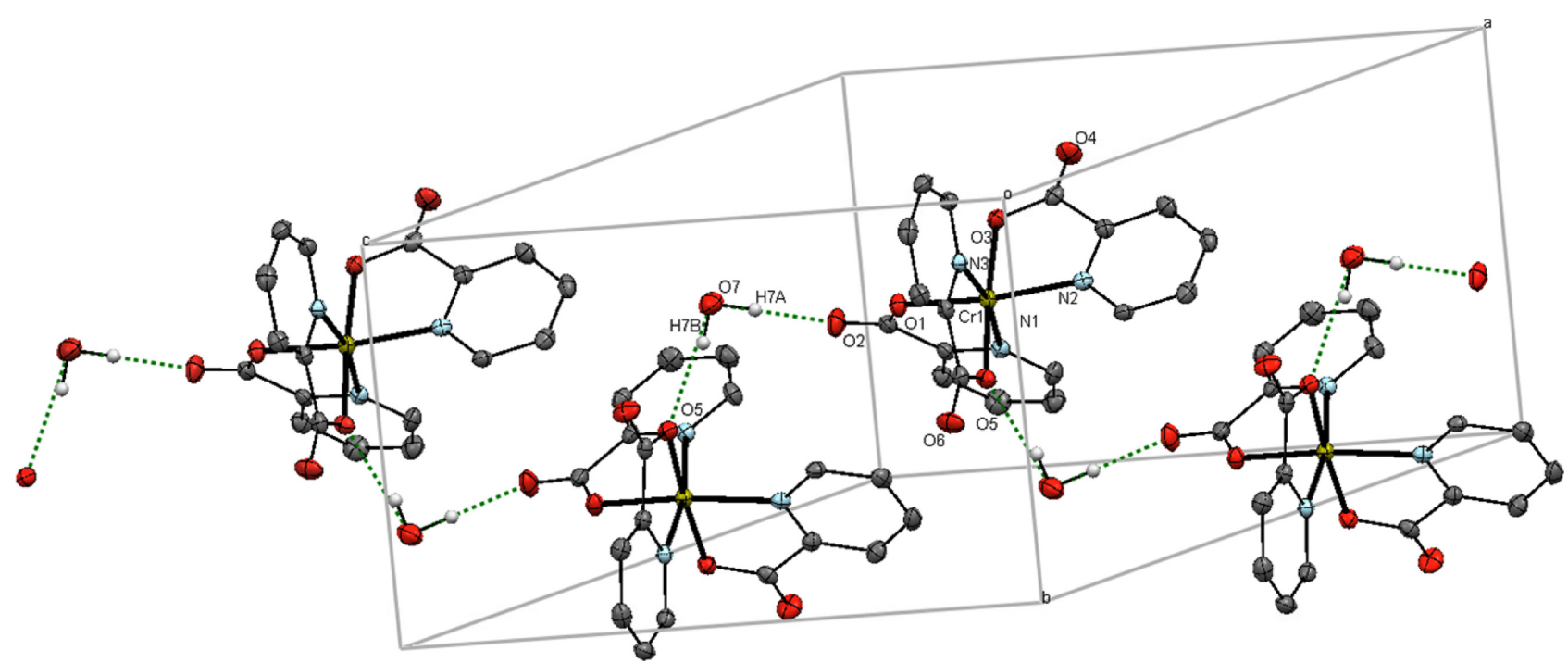

Figure 3. Packing of complex 1, showing the hydrogen bonds in $b c$ plane. Only the hydrogen atoms involved in hydrogen bonding are shown.

\section{CONCLUSION}

In this paper, the preparation of a chromium complex $\left[\mathrm{Cr}(\text { pic })_{3}\right] \cdot \mathrm{H}_{2} \mathrm{O}$ is presented and its spectral (IR, Raman) and structural properties is described. The crystal structure determination of 1 revealed that this crystal it is assembled from a chromium complex and a water molecule. The geometry around the chromium atom is distorted octahedral with $\mathrm{CrN}_{3} \mathrm{O}_{3}$ environment. In the crystal of $\mathbf{1}$, hydrogen bonds give raise to a supramolecular network.

Acknowledgments. We are grateful to Payame Noor University of I. R. Iran for financial support. And the publication cost of this paper was supported by the Korean Chemical Society.

\section{REFERENCES}

1. (a) Wachter, G. A.; Davis, M. C.; Martin, A. R.; Franzblau, S. G. J. Med. Chem. 1998, 41, 2436. (b) Jew, S.; et al. Bioorg. Med. Chem. Lett. 2003, 13, 609.

2. Li, G.; Qian, X.; Cui, J.; Huang, Q.; Zhang, R.; Guan, H. J. Agric. Food. Chem. 2006, 54, 125.

3. (a) Strearns, D. M.; Armstrong, W. H., Inorg. Chem. 1992, 31, 5178. (b) Gonzales-Vergara, E.; Hegenauer, J.; Saltman, P.; Sabat, M.; Ibers, J. A. Inorg. Chim. Acta 1982, 66, 115. (c) Grant-Mauk, A.; Coyle, C. L.; Bordignon, E.; Gray, H. B. J. Am. Chem. Soc. 1979, 101, 5054. (d) Libby, E.; Webb, R. J.; Streib, W. E.; Folting, K.; Huffman, J. C.; Hendrickson, D. N.; Christou, G., Inorg. Chem. 1989, 28, 4037. (e) Jfns, O.; Johansen, E. S., Inorg. Chim. Acta 1988,
151, 129. (f) Dixit, S. C.; Sharan, R.; Kapoor, R. N. Inorg. Chim. Acta 1989, 158, 109. (g) Li, W.; Olmstead, M. M.; Miggins, D.; Fish, R. H. Inorg. Chem. 1996, 35, 51.

4. (a) Hakimi, M.; Mardani, Z.; Moeini, K.; Fernandes, M. A. J. Coord. Chem. 2012, 65, 2221. (b) Hakimi, M.; Mardani, Z.; Moeini, K.; Schuh, E.; Mohr, F. Z. Naturforsch. 2013, 68b, 272. (c) Hakimi, M.; Mardani, Z.; Moeini, K.; Schuh, E.; Mohr, F. Z. Naturforsch. 2013, 68b, 267. (d) Hakimi, M.; Moeini, K.; Mardani, Z.; Schuh, S.; Mohr, F. J. Coord. Chem. 2013, 66, 1129. (e) Hakimi, M.; Moeini, K.; Mardani, Z.; Khorrami, F. J. Korean Chem. Soc. 2013, 57, 352. (f) Hakimi, M.; Mardani, Z.; Moeini, K.; Mohr, F.; Fernandes, M. A. Polyhedron 2014, 67, 27.

5. Nguyen, T.; Panda, A.; Olmstead, M. M.; Richards, A. F.; Stender, M.; Brynda, M.; Power, P. P. J. Am. Chem. Soc. 2005, 127, 8545 .

6. Groysman, S.; Villagran, D.; Nocera, D. G. Inorg. Chem. 2010, 49, 10759.

7. Cotton, F. A.; Rice, C. E.; Rice, G. W. Inorg. Chim. Acta 1977, 24, 231.

8. Monillas, W. H.; Yap, G. P. A.; Theopold, K. H. J. Chem. Cryst. 2011, 41, 415.

9. Hakimi, M.; Kukovec, B.-M.; Minoura, M. J. Chem. Crystallogr. 2012, 42, 290.

10. Dingwall, J. G.; Tuck, B. Angew. Chem. Int. Ed. Engl. 1983, 22, 498.

11. Ganesan, M.; Gabbai, F. P. Organometallics 2004, 23, 4608.

12. Koide, H.; Uemura, M. Tetrahedron Lett. 1999, 40, 3443.

13. Barr, R. D.; Green, M.; Marsden, K.; Stone, F. G. A.; Woodward, P. J. Chem. Soc., Dalton Trans. 1983, 507.

14. Braunstein, P.; Tiripicchio, A.; Tiripicchio-Camellini, M.; Sappa, E. Inorg. Chem. 1981, 20, 3586.

15. Braga, D.; Eckert, M.; Fraccastoro, M.; Maini, L.; Grepi- 
oni, F.; Caneschi, A.; Sessoli, R. New J. Chem. 2002, 26, 1280.

16. Aldridge, S.; Hashimoto, H.; Kawamura, K.; Shang, M.; Fehlner, T. P. Inorg. Chem. 1998, 37, 928.

17. Sheldrick, G. M. SADABS: Program for Empirical Absorption Correction of Area Detector Data, University of Gottingen: Gottingen, Germany, 1996.

18. Sheldrick, G. M. SHELXS/L-97: Program for Empirical Absorption Correction of Area Detector Data, University of Gottingen: Gottingen, Germany, 1997.

19. Spek, A. L. PLATON: A Multipurpose Crystallographic Tool, Utrecht University: Utrecht, The Netherlands, 2010.

20. Stearns, D. M.; Armstrong, W. H. Inorg. Chem. 1991, 31, 5178.

21. SAINT+: Bruker Advanced X-ray Solutions, version 7.60A; Bruker AXS Inc.; Madison, Wisconsin, USA, 2008.

22. (a) Hakimi, M.; Mardani, Z.; Moeini, K.; Mohr, F.; Schuh, E.; Vahedi, H. Z. Naturforsch. 2012, 67b, 452. (b) Hakimi,
M.; Mardani, Z.; Moeini, K. J. Korean Chem. Soc. 2013, $57,447$.

23. Hakimi, M.; Mardani, Z.; Moeini, K.; Minoura, M.; Raissi, H. Z. Naturforsch. 2011, 66b, 1122.

24. Nakamoto, K. In Infrared and Raman Spectra of Inorganic and Coordination Compounds, 6th ed.; John Wiley \& Sons: Hoboken, 2009; p 208.

25. (a) Farrugia, L. J. J. Appl. Crystallogr. 1997, 30, 565. (b) Burnett, M. N.; Johnson, C. K., ORTEP-III, Report ORNL6895. Oak Ridge National Laboratory, Oak Ridge, Tennessee, U.S.A., 1996.

26. Macrae, C. F.; et al. J. Appl. Crystallogr. 2008, 41, 466.

27. Hakimi, M.; Kukovec, B. M.; Minoura, M. J. Chem. Crystallogr. 2012, 42, 290.

28. Desiraju, G. R.; Steiner, T. In The Weak Hydrogen Bond: IUCr Monographs on Crystallography 9, Oxford University Press: Oxford, 1999; p 12. 